\title{
A REPLY TO PROFESSOR MORRIS' STATEMENT OF DISSENT
}

\section{ROBERT WARLDER}

I am grateful to Professor Morris for his challenge because it forces me to spell out implicit assumptions and to try to improve on my formulations.

There are essentially two issues at stake between Professor Morris and myself, one a matter of (moral) ideal, the other a matter of (psychological) fact.

The first issue is the question whether the concept of justice, or morality in general, is the same for all people and all times-an eternal essence in the Platonic heaven of ideas-or varies with time and place.

Without trying to formulate any moral philosophy of my own, I have merely noted, as an observer of human events, that very different kinds of order have been considered as just by different people, at different times; and furthermore, that the norms of Western civilization provide a basis for different and often contradictory claims.

That does not mean that every kind of action can be presented as just. Genocide, for instance, cannot be defended in terms of Western values or, for that matter, in terms of the values of any of the great historical civilizations; there is no moral tenet in any of them that would give one branch of the human race the right to exterminate another branch according to its pleasure.

But there is a large area within which more than one position can be argued in terms of traditional Western norms. A few examples may illustrate this point.

It is arguable that, in justice, all men should have a chance to realize their potential and to reach a place in society proportionate to their abilities and achievements. It is equally arguable that no man should derive any privileges from the fact that he was born with better health, greater endurance, higher intelligence or more creative ability, or had better opportunities for realizing his potential, than another man. It is even arguable that those more niggardly endowed by nature should be compensated for their privations.

It is arguable that in the name of justice, in a family or in an alliance of nations, all members, old or young, large or small, should participate equally in decision making. It is also arguable that the 
kind of equality which is just in such situations is not equality between members but is equality between power and responsibility in each member so that the voice of each has weight commensurate with the responsibility he carries for the consequences. According to the latter view, it would be unjust for the breadwinning father of a family to be outvoted by his minor children on a question of budgeting.

It is arguable that all members of a community have the right to be welcomed by other members with whom they wish to associate, and to live in the environment of their choice. It is also arguable that people have the right to associate or not to associate with others according to their pleasure or whim, and to congregate with those like-minded if they so desire.

In these and similar instances we do not have a clear division of right and wrong (as in the case of genocide) but a set of conflicting rights. It seems to me that in such cases the moral harvest is greatest if one approaches them "with charity towards all, with malice towards none" rather than by trying to impose one right at the expense of others.

This is essentially the view that Judge Learned Hand once expressed in his definition of justice as "a passable accommodation between the vital and self-conscious interests of society." 1

The second issue is a question of fact, viz., to what degree can nature be remolded so as to make her conform to moral requirements, and what price is to be paid in terms of other human values.

There are two extreme views on this issue: on the one hand the view of the Right which sees "human nature" as forever unchangeable, and on the other hand the Left view which holds that "society" can be so constructed as to make one's moral ideal a reality, at no appreciable costs to anything worth preserving.

I believe that both views are mistaken. There is no unchangeable human nature. It is "the nature of man to transcend nature," as Denis de Rougemont put it. ${ }^{2}$ All human history is the story of the transcendence of nature.

But, on the other hand, nature is not infinitely malleable. This is particularly true of living matter and more particularly of human beings. Moreover, interference with the natural course of things often has consequences beyond those intended; for instance, in medicine, the nocuous "side" effects of remedial drugs, radiation damage to healthy tissue, mutations of microorganisms attacked by antibiotics or iatrogenic diseases in general. These unintended consequences are not always easy to deal with. There is a point of diminishing

${ }^{1}$ L. Hand, The Speech of Justice, 29 HARv. L. REv. 617, 619 (1916).

${ }^{2}$ de Rougenont, The Christian Opportunity 173 (1963). 
returns beyond which further intervention is likely to be counterproductive, at least for the time being, or to exact a high price in terms of other human values.

A simple example of the limits with which egalitarian ideals meet in reality is provided by the history of the Soviet Union. Lenin started out to establish complete equality; all incomes were to be exactly equal and state power over the individual was to evaporate by itself. The results after fifty years are these: millionaire incomes have indeed been abolished but, apart from them, the spread of income is about as wide in the Soviet Union as it is in the West ${ }^{3}$ and is probably less flexible. In order to achieve this modest degree of egalitarianism, a far greater power of the state over the individual had to be established and maintained than had ever existed in the time of the Tsars. In order to avoid the reemergence of a prosperous merchant class, the Soviets recently found it necessary to decree the death penalty for "economic crimes," i.e., for private trading. ${ }^{4}$

That should also answer Professor Morris' question: "Shall we believe that since some are made so that we cannot down their aggressiveness in the form of status differentiation, others must inevitably be second class members of the human race?" 5

Stratification is a universal phenomenon of nature, both subhuman and human. It exists in every family, every nursery, every school class, every office or club. There is a hierarchy among monks, among martyrs and, of course, among fighters for egalitarianism. The great majority of people have to take not second but $n$th place.

Hierarchies can be re-shuffled, the rules of competition can be conventionalized and the prize of victory can be reduced; but they cannot be abolished altogether. Mitigation has been going on for a long time; the stakes-originally life and death-have been replaced by milder, or symbolic ones. The wages of defeat are no longer death but a lesser share in the amenities of life. Further mitigation is no doubt possible. But it is not certain that the frustrations of the losers have lessened in proportion to the amount by which the stakes have become less deadly.

Full equality cannot be achieved by voluntary cooperation alone; it needs a new hierarchy of supervisors. Being human, they will come to use their powers for their own aggrandizement, too.

3 Kuznets, Quantitative Aspects of the Economic Growth of Nations: VIII. Distribution of Income by Size, 11 Economic Development \& Cultural Change 22 (1963). 1966).

4 Soviet Criminal Law and Procedure 61, 62, 188 (Berman \& Spindler transl.

5 Morris, A Dissent to Dr. Waelder's Theory of Justice, 115 U. PA. L. Rev. 12 (1966) [hereinafter cited as Morris]. 
Moreover, it may be questioned whether complete abolition of the struggle leading to status differentiation, if possible, would be entirely desirable. Educators have often criticized the "overprotectiveness" of some parents who wish to spare their children the encounter with more aggressive youngsters. They think that this kind of protectiveness is not in the children's own long term interest; short of protection against extreme abuse, children should be allowed to develop their own maximum strength under challenge, thus finding, and eventually accepting, a place in the group which is commensurate with their capabilities.

Professor Morris sees moral progress toward equality in developments in which I can see only a growth of abundance which removes inequalities on one level only to have them reappear on another level. "In some ancient societies," Professor Morris states, "only a tycoonfather could afford to send daily letters by a private messenger to his distant son. Today our postal system has equalized (or almost so) that opportunity . . . . In this petty sphere we have equalized both opportunity and station. This insignificant example can be multiplied many times; we now enjoy many equalities of opportunity and station undreamed of a few generations ago." 6

To my mind, this is merely a consequence of progress in technology and wealth. A few centuries ago, postal transportation was so expensive that it could not be available to more than a few; today, we have become technologically so efficient that we can handle hundreds of millions of pieces of mail every day at modest expense.

But the very technological progress which removes scarcity in some areas, and with it the need for differential allocation and the question of its justice, opens new, previously undreamed of possibilities which are, for some time at any rate, just as scarce. What was the case with postal services at the time of Lord Chesterfield is now the case with, say, fine suburban homes in an attractive countryside or with elegant new automobiles. Inequalities in these matters are now bitterly resented. There are also the advances of modern medicine-marvelous but enormously expensive-which cannot, or cannot quickly, be made equally available to all; there is not a sufficient number of highly trained and experienced specialists to give everybody the care which is currently available in only a few outstanding centers. This is a cause of the great indignation of social critics who call it "the shame of American medicine." 7

6 Morris 15.

7 Langer, The Shame of American Medicine, New York Review of Books, May 26, 1966, p. 6. 
It seems safe to predict that when there is a sufficient number of highly skilled professionals and a sufficient supply of modern gadgetry, there will be new inventions requiring even greater skill and more sophisticated machinery which, for some time at least, will be available only to a minority; and that will probably be considered an even greater shame. The issue continuously recurs on a higher level; technological progress and growing wealth create new inequalities as fast as they remove old ones.

The question of just distribution becomes an issue only where goods or benefits are scarce. But scarcity is an unpleasant predicament; thus Professor Morris refers to my example of the parents who can either send three normal children to college or provide for one retarded child such remedial training as may keep it out of institutions, and comments that "these agonized parents cannot act justly." 8 Just distribution, for Professor Morris, is apparently possible only where the supply is sufficiently plentiful so that everyone can get what we would like him to have. To my mind, the question of justice does not even arise in these happy circumstances.

Professor Morris finds me "more than just negatively complacent." This interpretation of my motivation and attitude is based on an insufficient familiarity with the facts. As an immigrant from Europe and, in particular, a refugee, I have looked more closely into the abyss of human privation and degradation than have most native Americans. It is precisely because I know what human destiny can be like, and because I know how fragile is the modicum of civilization that we enjoy, that I am alarmed by the present tidal wave of militant utopianism which is daily weakening, and may well destroy, a society which, while certainly far from perfect in terms of the Sermon from the Mount, is yet the most humane the world has so far known. Once people expect from the institutional set-up not merely a guarantee of life, liberty and the pursuit of happiness and "a passable accommodation between the vital and self-conscious interests of society" " but the creation of a "just society," things seem to me to be headed for disaster, because a state of affairs which is acknowledged as just by all is not possible and the constant stimulation of hopes which must remain unfulfilled can only be explosive.

8 Morris 15.

9 L. Hand, supra note 1 , at 619. 